\title{
Growth of young-of-the-year European anchovy (Engraulis encrasicolus, L.) in the Bay of Biscay
}

\author{
NAROA ALDANONDO, UNAI COTANO and EGOITZ ETXEBESTE \\ AZTI-Tecnalia, Marine Research Unit, Herrera Kaia Portualdea z/g, 20110, Pasaia, Basque Country, Spain. \\ E-mail: naldanondo@gmail.com
}

\begin{abstract}
SUMMARY: Otolith daily increment analysis was used to describe the first growth season of young-of-the-year anchovy (Engraulis encrasicolus L.) in the Bay of Biscay. Anchovy larvae and juveniles were sampled during their growth season over a three year period $(2004,2005$ and 2006). A logistic curve was fitted to the length at age data. At the end of the first year of growth, length was $168.3 \mathrm{~mm}$, with a maximum growth rate of $1.85 \mathrm{~mm} \mathrm{day}^{-1}$ for 73 days after hatching. Moreover, a Gompertz growth model was applied to estimate otolith growth parameters. At the end of the first year the otolith radius was $1759 \mu \mathrm{m}$, with a maximum growth increment of $22.19 \mu \mathrm{m}_{\text {day }}{ }^{-1}$ observed 56 days after hatching. Standard length and otolith radius were closely related; however, this relationship showed a characteristic change from exponential in the larval stage to linear in the juvenile stage.
\end{abstract}

Keywords: Bay of Biscay, early life stage, European anchovy, fish length-otolith radius relationship, growth, otolith.

RESUMEN: CRECIMIENTO DE LA ANCHOA EUROPEA (ENGRAULIS ENCRASICOLUS, L.) EN EL GOLFO DE BizKaia DURANTE LAS ETAPAS TEMPRANAS DE SU CICLO DE VIDA. - Este trabajo describe el crecimiento de las etapas tempranas del ciclo de vida de la anchoa europea (Engraulis encrasicolus L.) en el golfo de Bizkaia mediante el análisis de la microestructura de los otolitos. Se capturaron larvas y juveniles de anchoa durante su periodo de crecimiento en tres años (2004, 2005 y 2006). El modelo de crecimiento logístico se ajustó a los datos de las tallas por edad. Al final del primer año de crecimiento, la talla estimada para la anchoa fue de $168.3 \mathrm{~mm}$, con una tasa máxima de crecimiento de $1.85 \mathrm{~mm}$ día $^{-1}$ a los 73 días después de la eclosión. Además, se aplicó el modelo de crecimiento Gompertz para estimar los parámetros de crecimiento del otolito. Al final del primer año, el radio estimado del otolito fue de $1759 \mu \mathrm{m}$, y la tasa de crecimiento máxima de $22.19 \mu \mathrm{m}$ día $^{-1}$ se obtuvo a los 56 días después de la eclosión. Se observó una estrecha relación entre la longitud estándar y el radio del otolito; sin embargo, mientras que en la fase larvaria dicha relación es exponencial, en el caso de los juveniles, pasa a ser lineal.

Palabras clave: anchoa europea, crecimiento, etapas tempranas, golfo de Bizkaia, otolito, relación longitud estándar-radio del otolito.

\section{INTRODUCTION}

In the Bay of Biscay, European anchovy (Engraulis encrasicolus L.) is an important species from both an ecological and commercial point of view (Uriarte et al., 1996). In this region, anchovy spawns primarily in highly productive areas, such as the Gironde and Adour river plumes, and partially on the shelf break. The spawning season extends from March to August with a maximum intensity peak between May and June (Motos et al., 1996; Bellier et al., 2007). The predominant north-easterly winds during summer transport larvae towards off-shelf waters. Consequently, the age and size of larvae increase from the river plumes to off the shelf (Cotano et al., 2008). In autumn, the juvenile distribution also shows a size- and age-dependent gradient, but in this case, this distribution is the opposite to that of eggs and larvae. Relatively small and young juveniles are found off the shelf, whereas larger and older individuals are caught in the area influenced by the Gironde river plume (Aldanondo et al., 2010).

Annual recruitment is especially critical for anchovy mainly due to a complex life history coupled with a short life cycle. These two factors result in population 
biomass depending on the strength of 1-year-old annual recruitment (Borja et al., 1996, 1998). In fact, in years with average recruitment, 1-year-old individuals comprise around $70-80 \%$ of the spawning population the following year, and therefore annual recruitment success depends on larval and juvenile survival in the previous summer (Irigoien et al., 2007). The population of European anchovy in the Bay of Biscay has undergone large interannual and interdecadal fluctuations in abundance (Uriarte et al., 1996; Borja et al., 1998). After several continuous recruitment failures since 2001, the stock of anchovy decreased until it collapsed in 2005, with the subsequent closure of the fishery (ICES, 2007).

Growth has been established as a critical parameter in the survival and subsequent recruitment of larval and juvenile marine fishes (Houde, 1989). In general, it has been suggested that individuals with the highest growth rates have a better chance of surviving due to the reduction in time at the most vulnerable stage (Anderson, 1988). Furthermore, it is known that large fluctuations in fish recruitment could be caused by a relatively small variation in growth during early life stages (Houde, 1989). Hence, knowledge of the growth rate of anchovy during early life stages is essential for understanding year class success and survival.

Otolith microstructure analysis is a useful tool for studying age, growth and mortality of larvae and juvenile fish (Folkvord et al., 2004; Hinrichsen et al., 2007). This technique is based on the assumption that the increments in the otoliths are deposited at the rate of one per day, and that the age of the individuals can be estimated by counting these structures (Ivarjord et al., 2008). Moreover, otolith size and fish size are highly correlated for a variety of marine species, and when this relationship is predictable, growth trajectories and histories can be back-calculated based on otolith increment width (Geffen, 1982; Campana and Neilson, 1985; Moksness, 1992). However, given the potential use of the otolith as an individual record of size and growth, it is important to examine the factors that might affect this relationship (Hare and Cowen, 1995) because several examples of variable relations between fish growth and otolith growth have been documented (Mosegaard et al., 1988; Folkvord et al., 1996).

The literature on European anchovy growth during the early life stages is limited. Several studies have previously described larval growth of this species based on length at age data (Palomera et al., 1988; García et al., 2003; Cotano et al., 2008). Nevertheless, studies that include both larval and juvenile stages are scarce in the literature and they do not address the issue of growth modelling (Allain et al., 2003; Wilhelm et al., 2005; Cermeño et al., 2008).

The aims of the current study were: (1) to describe both the somatic and otolith growth of anchovy during the first growth season in the Bay of Biscay; and (2) to evaluate the ontogenetic effect on the otolith sizefish size relationship and the potential impact on the proportionality of otolith growth and somatic growth.

\section{MATERIALS AND METHODS}

\section{Sample collection}

Five surveys were carried out in the southeastern part of the Bay of Biscay (limited to $6^{\circ} \mathrm{W}$ and $47^{\circ} 30^{\prime} \mathrm{N}$ ) over a period of three years $(2004,2005$ and 2006). Anchovy larvae and juveniles were sampled during their growth season in summer-autumn. The surveys covered the potential larvae and juvenile distribution areas between the Spanish coast and the continental shelf off Gironde (Irigoien et al., 2007; Cotano et al., 2008).

Anchovy larvae were sampled over a grid of stations distributed in coastal perpendicular transects in June 2004 and August 2005. Larvae were collected using a double Bongo net with $40 \mathrm{~cm}$ mouth diameter and $335 \mu \mathrm{m}$ mesh size. The tows were oblique from the surface to a depth of $70 \mathrm{~m}$, or to $5 \mathrm{~m}$ above the bottom in shallower waters. In order to obtain large larvae, a MIK (Methot Isaac Kidd) net with $1 \mathrm{~mm}$ mesh size was employed. The samples were preserved in $80 \%$ buffered ethanol until further analysis. Juveniles were sampled in September-October 2004, 2005 and 2006 within the framework of the JUVENA acoustic survey. The basic sampling scheme was based on cross-shelf transect lines from the coast $(20 \mathrm{~m}$ bottom depth) to beyond the self break. Juveniles were caught by purse seines $(400 \mathrm{~m}$ in perimeter, $75 \mathrm{~m}$ height and $4 \mathrm{~mm}$ mesh size) and pelagic trawl nets (4 mm mesh size in the cod end), and frozen after being measured to the nearest $\mathrm{mm}$ for standard length (SL) on board. The surveys and sampling details are described fully in Cotano et al. (2008) and Irigoien et al. (2008).

\section{Otolith analysis}

In the laboratory, SL was measured to the nearest $0.1 \mathrm{~mm}$ for larvae and juvenile anchovy. Juvenile SL was corrected for shrinkage using a conversion factor of 1.019 (unpublished data). In order to obtain a representative sample of the whole area and range of lengths, individuals from different locations (Fig. 1) and for all length ranges were processed. Sagittal otoliths were removed and processed following the same methodology as the one used in Aldanondo et al. (2008) for larvae and Aldanondo et al. (2010) for juveniles. For juveniles, right sagittal otoliths were used for the analyses. Otoliths were analysed using a light microscope coupled with an image analyser (Visilog, TNPC Software, v.3.2, Ifremer, France). Larvae and the central part of juvenile otoliths were read at $\times 1000$ magnification in immersion oil. The outer part of juvenile otoliths was analysed at $\times 100$ magnification. All increments were counted starting at hatch increment (Aldanondo et al., 2008) and otolith radius (OR) was measured along the same axis from the core to the edge of the otolith on the post-rostrum side. The criteria described by Cermeño et al. (2008) were followed for daily increment interpretation. Each otolith was read independently by two 

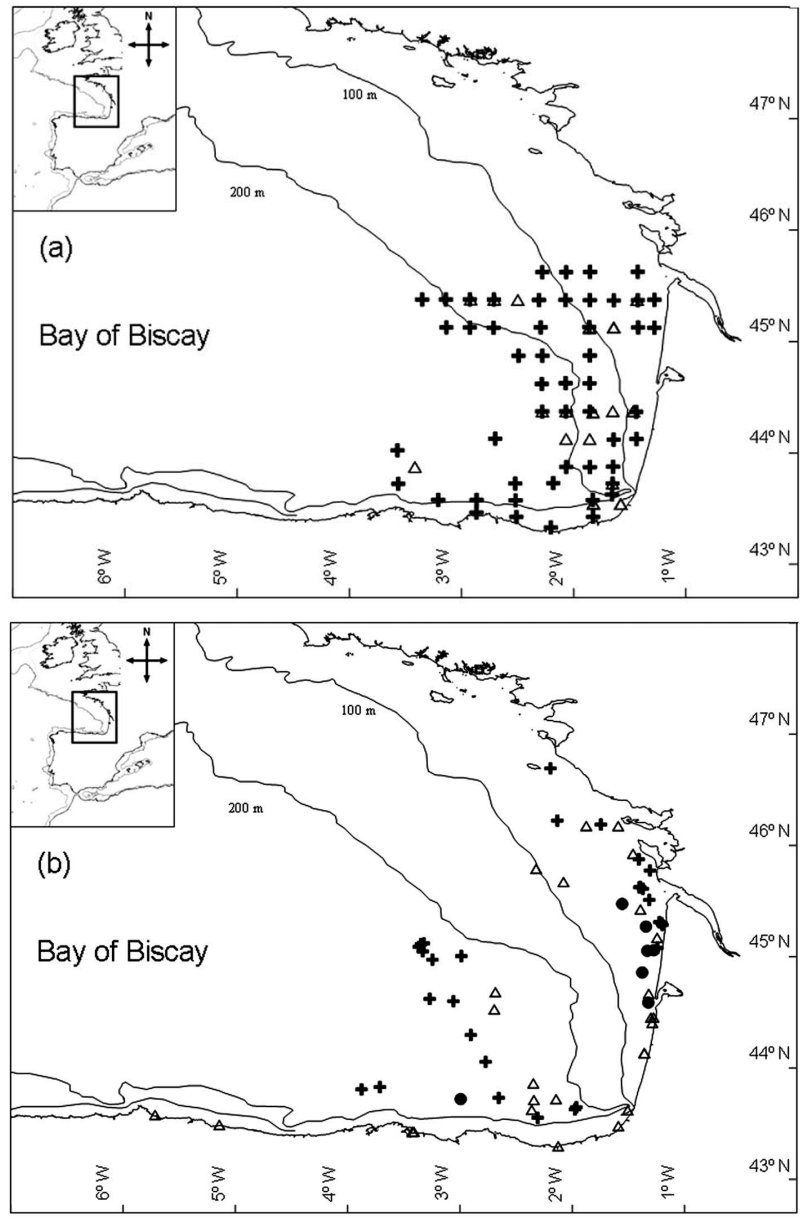

FIG. 1. - Location of the study area in the Bay of Biscay. (a) Larval otolith sampling location is representing by crosses in 2004 and triangles in 2005. (b) Juvenile otolith sampling location is illustrated by dots in 2004, crosses in 2005 and triangles in 2006.

readers; every otolith with a difference between readers higher than $5 \%$ was rejected. For the rest, a third common interpretation was carried out and the result was recorded only if an agreement was reached. A total 336 larvae and 224 juveniles was fully processed.

As daily increment deposition has been validated for European anchovy larvae (Aldanondo et al., 2008) and juveniles (Cermeño et al., 2003), the increment number was considered a proxy of age in days.

\section{Data analysis}

Data of length at age and otolith radius at age were fitted to different growth models: logistic, Gompertz and von Bertalanffy. Both the logistic and Gompertz models showed adequate fits to the data; however, a von Bertalanffy model did not describe growth during the first growth season, and thus it was removed from the analysis.

The following formulations of the logistic (Ricklefs, 1967) (1) and the Gompertz (Ricker, 1979) (2) model growth equations were used:

$$
\begin{gathered}
L_{t}=\frac{L_{\infty}}{1+\exp ^{-k\left(t-t_{0}\right)}} \\
L_{t}=L_{\infty} \exp ^{-\exp ^{-K\left(t-t_{o}\right)}}
\end{gathered}
$$

where, $L_{t}$ is the $\mathrm{SL}(\mathrm{mm})$ or OR $(\mu \mathrm{m})$ at $\mathrm{t}$ days from hatching, $L_{\infty}$ is the asymptotic $\mathrm{SL}(\mathrm{mm})$ or OR $(\mu \mathrm{m})$ at the end of the first growth year, $k$ is the instantaneous growth rate when tends to $t_{0}, t$ is the number of days from hatching and $t_{0}$ is the abscissa of the inflection point, which corresponds to the maximum growth rate. These parameters were derived with the nolinear least squares method. Finally, as the variance in length was not homogeneous, a weighting factor equal to the inverse of age was introduced into the least-squares analysis to yield parameter estimates with the smallest variance (Box et al., 1978). Daily growth was estimated as the difference in SL between consecutive days.

Differences in otolith growth trajectories were assessed based on daily increment widths. Given that daily growth data is auto-correlated, since the same individuals are compared at different ages, repeatedmeasures multivariate analysis of variance (MANOVA) was used to compare individual growth trajectories (Chambers and Millers, 1995; Meekan and Fortier, 1996). As variance increased with age, increment width data sets were natural log-transformed prior to analysis. Comparisons were made between groups with the null hypothesis of no differences, and Wilk's $\Lambda$ was used as the statistical test.

\section{RESULTS}

Anchovy SL ranged between 3.1 and $146.8 \mathrm{~mm}$ for individuals of between 1 and 108 days old. Length at age data was well described by logistic and Gompertz models. The two curves employed to describe anchovy growth during the first growth season explained a high percentage of the variability in $\operatorname{SL}\left(R^{2}=0.95\right)$. Residual values obtained for both curves were quite similar during larval and juvenile stages (Fig. 2). However, the two models obtained different estimates for growth parameters (Table 1). Considering these values, a logistic model was selected to describe anchovy growth (see Discussion). According to the growth curve, a mean length of $168.3 \mathrm{~mm}$ SL was reached at the end of the first growth season, and a maximum somatic growth of $1.85 \mathrm{~mm}$ day $^{-1}$ was found at 73 days after hatching (Fig. 3).

TABLE 1. - Estimates of somatic growth parameters for young-ofthe-year anchovy in the Bay of Biscay. $L_{\infty}$, asymptotic standard length $(\mathrm{mm}) ; k$, growth coefficient; $t_{0}$, the abscissa of the inflection point (days).

\begin{tabular}{lcccc}
\hline & \multicolumn{2}{c}{ Logistic } & \multicolumn{2}{c}{ Gompertz } \\
& Estimate & SE & Estimate & SE \\
\hline$L_{\infty}$ & 168.3 & \pm 0.69 & 336.3 & \pm 3.90 \\
$k$ & 0.044 & \pm 0.001 & 0.015 & \pm 0.001 \\
$t_{0}$ & 73.93 & \pm 2.13 & 96.20 & \pm 7.27 \\
\hline
\end{tabular}



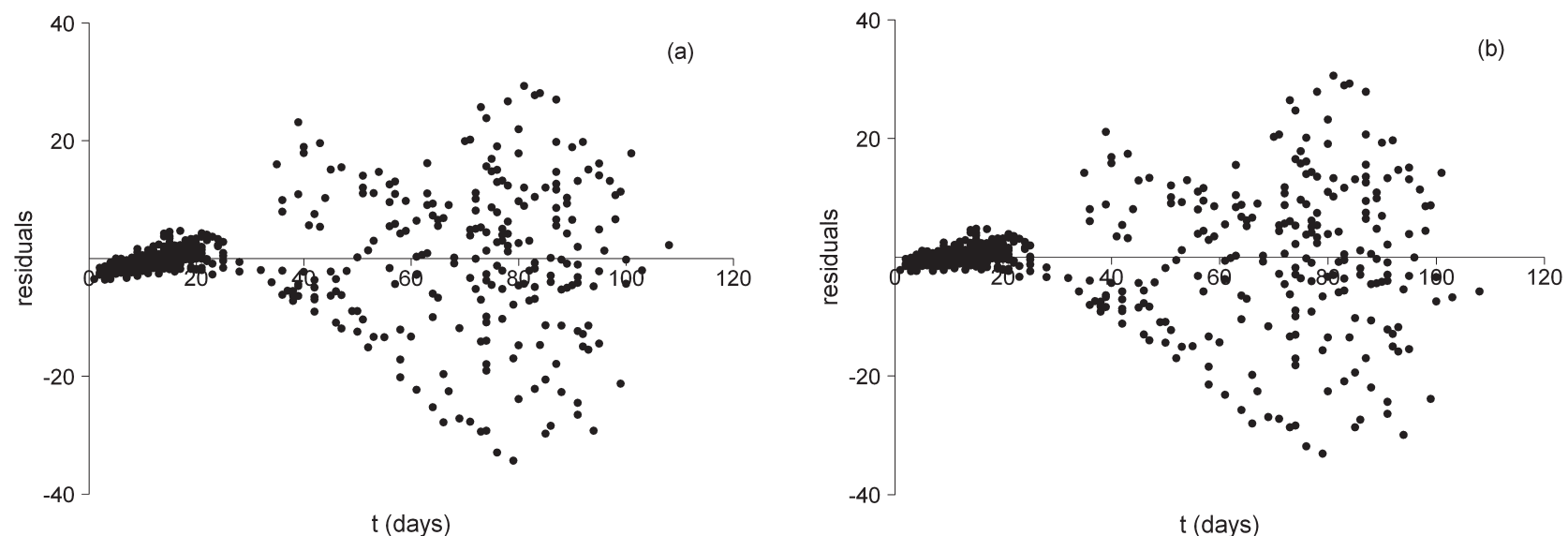

FIG. 2. - Plots of standard length residual values for (a) logistic and (b) Gompertz growth equations at age.

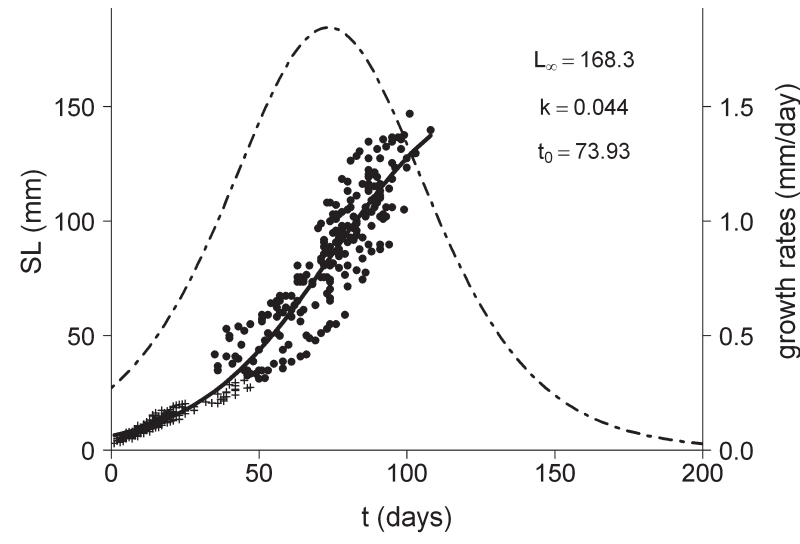

FIG. 3. - Logistic curve (solid line) fitted to standard length (SL) at age $(\mathrm{t})$ data. Daily growth rates (broken line) have also been plotted considering the difference in standard length between consecutive days obtained with the logistic curve. The crosses represent the larvae and the dots the juveniles. $L_{\infty}$, asymptotic standard length $(\mathrm{mm})$; $k$, growth coefficient; $t_{0}$, the abscissa of the inflection point (days).

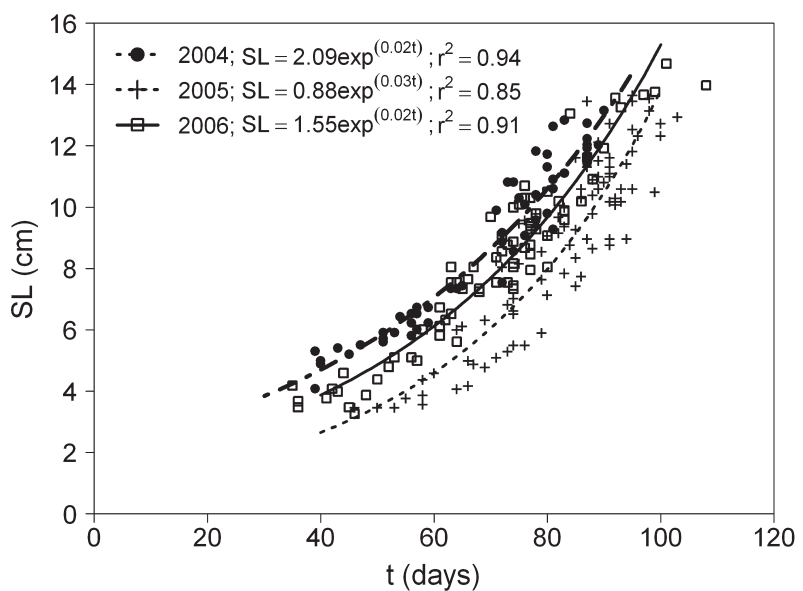

FIG. 4. - General growth pattern of juveniles sampled in different years. $S L$, standard length; $t$, age.

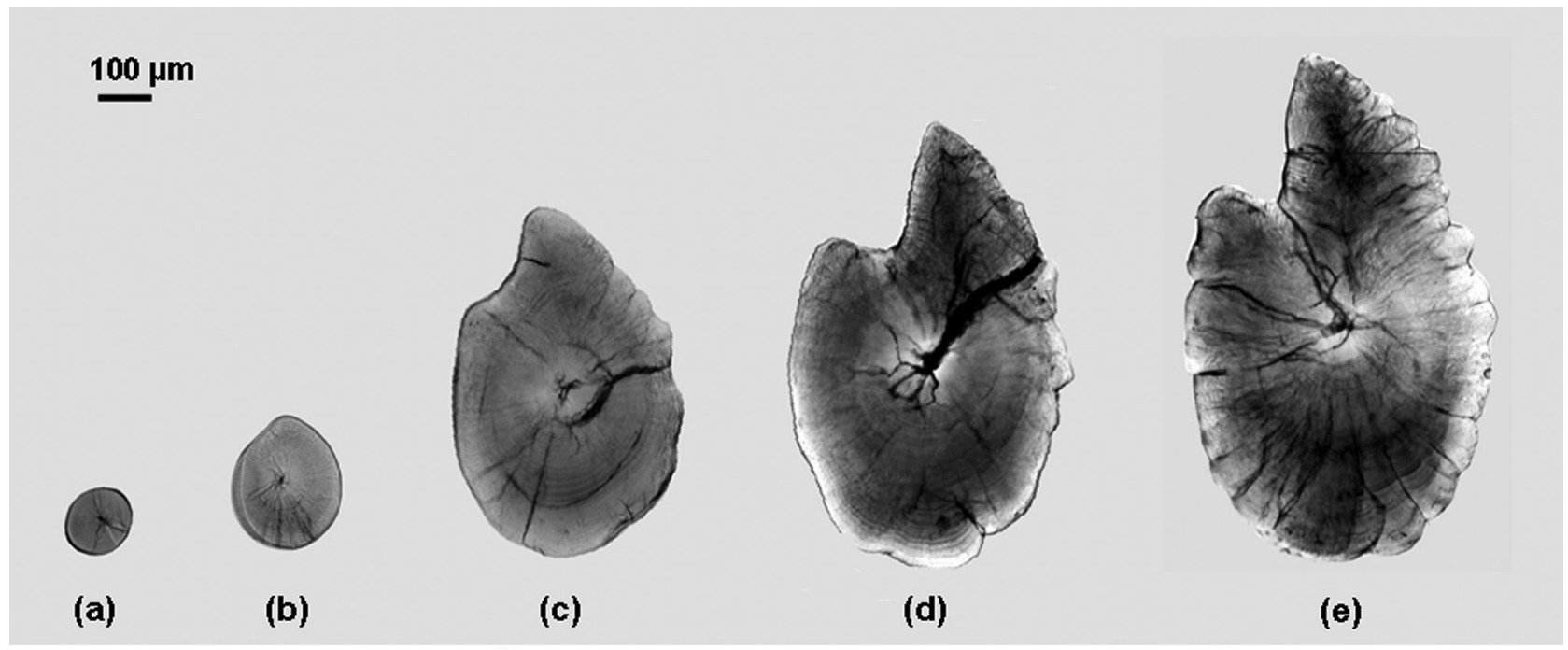

FIG. 5. - Morphological development of European anchovy sagittal otolith during larval and juvenile stages. (a) 14 mm in length anchovy, (b) $21 \mathrm{~mm}$ in length anchovy, (c) $29.6 \mathrm{~mm}$ in length anchovy, (d) $31.2 \mathrm{~mm}$ in length anchovy, (e) $39.8 \mathrm{~mm}$ in length anchovy. 

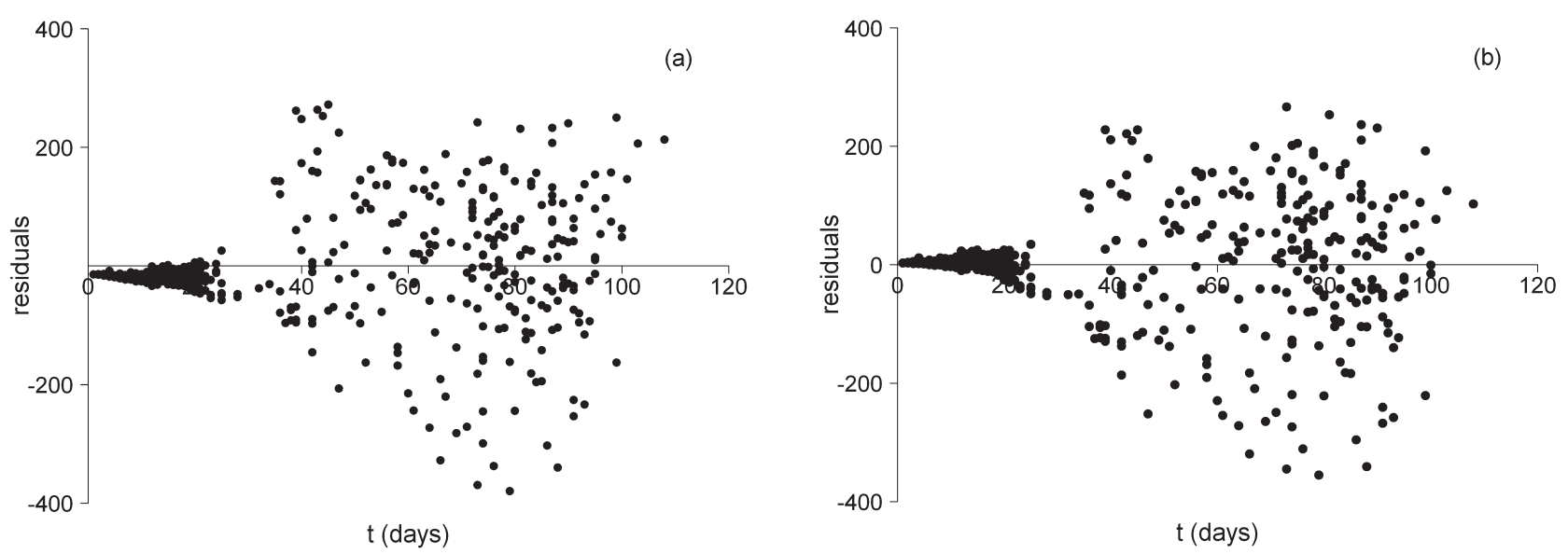

FIG. 6. - Plots of otolith radius residual values for (a) logistic and (b) Gompertz growth equations at age.

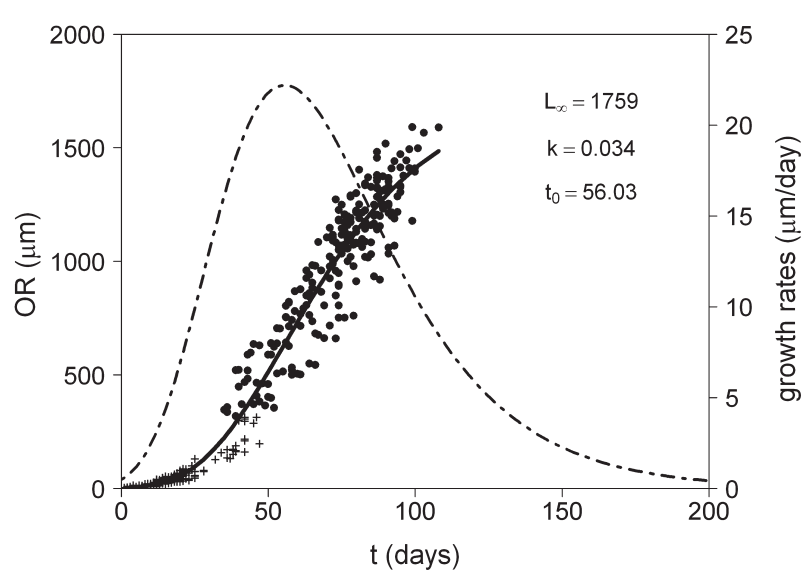

FIG. 7. - Gompertz curve (solid line) fitted to otolith radius (OR) at age (t) data. Daily growth increments (broken line) have also been plotted considering the difference in otolith radius between consecutive days obtained with the Gompertz curve. The crosses represent the larvae and the dots the juveniles. $L_{\infty}$, asymptotic otolith radius $(\mu \mathrm{m}) ; k$, growth coefficient; $t_{0}$, the abscissa of the inflection point (days).

Likewise, the length at age relationship for each year was analysed for anchovy juveniles (Fig. 4). This relationship was described well by exponential regression and significant differences between the slopes of these curves were found (ANCOVA, $P<0.05$ ). The juvenile population in 2004 had the highest growth rate $(0.95 \mathrm{~mm}$ $\mathrm{d}^{-1}$ at 40 days). The estimated growth for the individuals sampled in 2005 was $0.73 \mathrm{~mm} \mathrm{~d}^{-1}$ at 40 , and this value increased to $0.89 \mathrm{~mm} \mathrm{~d}^{-1}$ for the 2006 population.

In relation to sagittal otolith development, the otolith was circular in shape for larvae under $15 \mathrm{~mm}$ in SL, since the antero-posterior axis was not distinguishable (Fig. 5a). The otolith shape then changed and became elongated as growth was more intense along this axis (Fig. 5b, c). In addition, fold structures were observed at the margin of the otolith (Fig. 5d). At this stage, the otolith resembled the adult otoliths in individuals over $30 \mathrm{~mm}$ in SL (Fig. 5e).

Otolith radius at age data was also described by the logistic and Gompertz models. The two curves

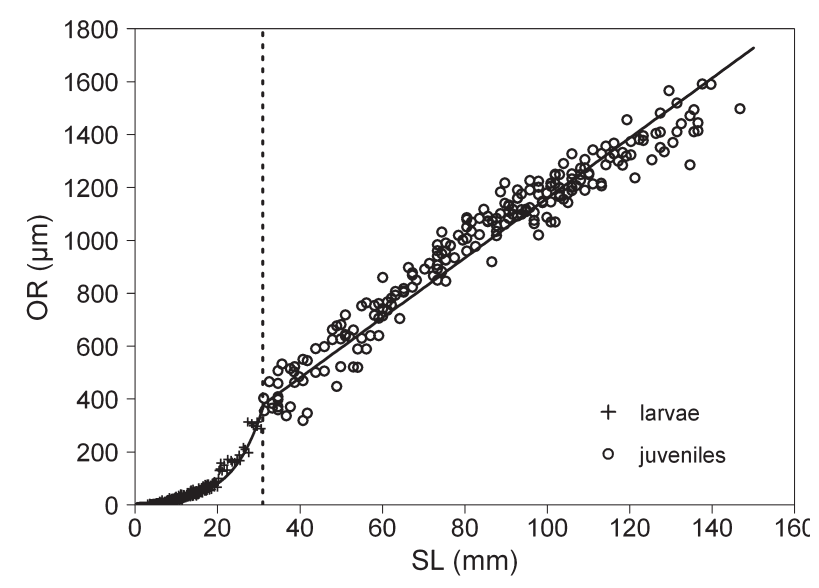

FIG. 8. - Regressions of otolith radius (OR) on standard length (SL) for larvae and juveniles. Vertical dashed line shows the split between larvae and juveniles.

employed to describe otolith growth during the first growth season explained a high percentage of the variability in OR $\left(R^{2}=0.97\right)$. Residual values obtained from logistic and Gompertz curves were quite similar although smaller for the latter during the larval stage (Fig. 6). In fact, negative values were observed for the logistic model during this stage, which suggests an overestimation of OR. Thus, the Gompertz model was used to fit otolith radius at age data. Anchovy OR at the end of the first growth season was $1759 \mu \mathrm{m}$ and a maximum growth of $22.19 \mu \mathrm{m}$ day $^{-1}$ was found at 56 days after hatching (Fig. 7).

The relationship between OR and SL was high and significant, and was expressed as an exponential function for larval stage $\left(O R=3.85 \exp ^{0.16 S L}, \mathrm{n}=336\right.$; $\left.R^{2}=0.93 ; P<0.001\right)$. However, this relationship showed a marked change and was given by a linear function for the juvenile stage $(O R=102.72+10.56 S L, \mathrm{n}=224$; $R^{2}=0.95 ; P<0.001$ ) (Fig. 8).

The otolith daily growth patterns were compared for larvae and juveniles during their larval stage (repeatedmeasures MANOVA, Table 2, Fig. 9). The sampled larvae had the narrowest increment throughout the first 
TABLE 2. - Results of repeated-measures MANOVA comparisons of individual growth trajectories.

\begin{tabular}{llcccrr}
\hline Stage & Source & \multicolumn{2}{c}{$\mathrm{df}$} & Wilk's $\Lambda$ & $F$ & $P$ \\
& & Numerator & Dominator & & & \\
\hline Larvae/Juveniles & Stage & 1 & 241 & 0.7604 & 75.9 & $<0.001$ \\
& Age & 1 & 215 & 0.0110 & 712.3 & $<0.001$ \\
& Stage $\times$ Age & 1 & 215 & 0.5750 & 5.8 & $<0.001$ \\
\hline
\end{tabular}

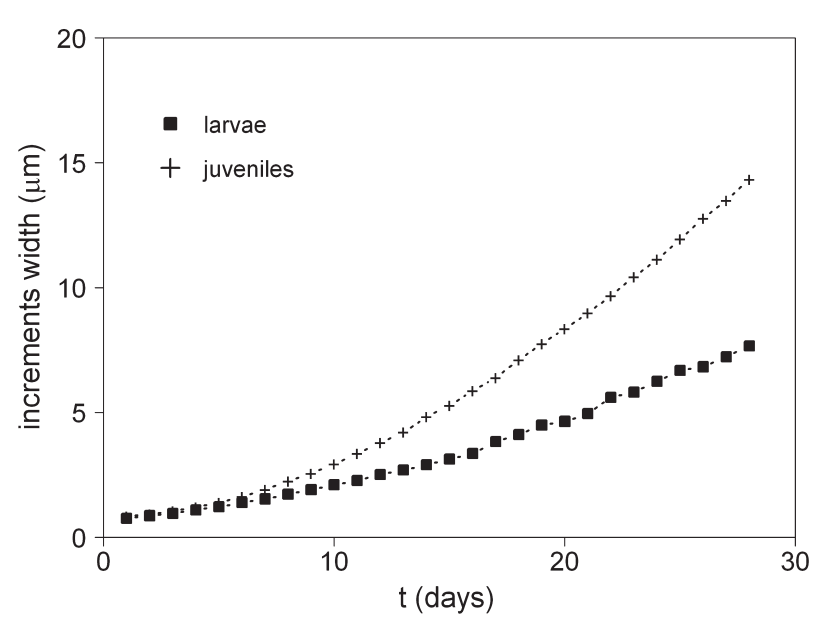

FIG. 9. - Average otolith increment widths at age (t) for larvae and juveniles during their larval stage.

28 days. The juveniles showed a different trend and there were significant differences between the trends for larvae and juveniles (Wilk's $\Lambda=0.57, P<0.001$ ).

\section{DISCUSSION}

The degree of size selection is an important issue in age and growth studies since growth varies among individuals of a cohort (Butler, 1992). In the current study, the whole size range from larvae to juveniles was covered by the gears used (Bongo, MIK, purse seine and pelagic trawl). However, the methodology applied is not free from specific sources of uncertainty, and so the sampled otolith data may be biased. It is known that the maximum size of larvae collected in plankton nets is mainly determined by net avoidance, which is a function of individual size and condition (Butler, 1992; Somarakis et al., 1998). Therefore, there is a strong possibility that among older larvae plankton nets would tend to catch those with a lower growth rate, since fast growing individuals would have reached a size and movement capabilities that would allow them to avoid nets. This effect has been checked when individual growth trajectories for larvae and juveniles during their larval stages were compared (Fig. 9). This would lead to an underestimation in the growth calculation. Another potential source of bias may come from the beginning of aggregation in the size range 10$15 \mathrm{~mm}$ in SL (Cotano et al., 2008). When present, this size class was efficiently captured in the MIK, but as it appeared aggregated in space, the equidistant sampling gear was not adequate. In addition, the schools were still too small to be identified by acoustics (Irigoien et al., 2008). These effects were observed for the larval data set used in this study (Figs. 3 and 7).

It was necessary to group data from different years (2004, 2005 and 2006) in order to cover the age range as much as possible, although this grouping may have affected the general growth pattern (Simard et al., 1992). Interannual variability in growth for anchovy has not been previously reported in the Bay of Biscay. However, this seems to be due to the lack of studies on this issue because significant differences in growth were observed in the present studies. Nevertheless, as Simard et al. (1992) stated, including data from different years may be considered as an advantage, since it provides a general description of the growth pattern.

The statistical analysis suggested that a logistic curve was the best equation for explaining growth in length for anchovy during their first growth season. It should be noted that this model did not describe anchovy growth satisfactorily during the early larval stage (Fig. 3), as it overestimated the length of newly hatched larvae. This may be due to the lack of faster growing late larvae in the growth model data, and therefore the inclusion of such data would improve the logistic model fitting. Several studies have previously described the growth of this species with a von Bertalanffy model based on adult length at age data (Morales-Nin and Pertierra, 1990; Bellido et al., 2000; Basilone et al., 2004). Nonetheless, studies on the early life stages of anchovy, particularly those that include both larval and juvenile stages, are scarce in the literature and they do not address the issue of growth modelling (Allain et al., 2003; Wilhelm et al., 2005; Cermeño et al., 2008).

The results obtained indicate that the $L_{\infty}$ reached by anchovy at the end of their first season varied significantly between populations. The $L_{\infty}$ obtained in the present study $(168.3 \mathrm{~mm})$ is significantly higher than those published by Bellido et al. (2000) and Basilone et al. (2004), which back-calculated a mean body length at the first annulus of 113 and $116 \mathrm{~mm}$ respectively. However, the significance of these differences is doubtful, since the calculation of this coefficient is considerably affected by the range of individuals used in the analysis.

Size at the end of the first growing season reflects both larval and juvenile growth. The $L_{\infty}$ yielded by the logistic model (168.3 mm) falls within the range of 105 to $180 \mathrm{~mm}$ in length reported for 1-year-old anchovy in the Bay of Biscay (Junquera and Perez-Gándaras, 1993), resulting in a reliable length estimator. However, the Gompertz model did not provide a realistic estimation of length $(336.3 \mathrm{~mm})$, although this may be 
due to the lack of older juveniles in the growth model data. In this sense, an additional juvenile sampling in late autumn would improve the Gompertz model fitting. Although both models displayed similar goodness of fit and distribution of residuals, when the estimated parameters were considered, the logistic model was selected over the Gompertz model in order to describe anchovy growth.

The average growth rate estimated by the logistic model during the larval stage (for larvae younger than 30 days old) is $0.6 \mathrm{~mm}$ day $^{-1}$. This value is similar to those observed by Cermeño et al. (2008) and Cotano et al. (2008) in the same area, which estimated a mean growth during the larval stage of 0.65 and $0.61 \mathrm{~mm}$ day $^{-1}$ respectively. Furthermore, the mean growth rate calculated in this study is within the range of 0.40 to $1.0 \mathrm{~mm}$ day $^{-1}$ reported for this species in Mediterranean waters (Palomera et al., 1988, 2007; García and Palomera, 1996; Dulčić, 1997; García et al., 2003). The estimated maximum somatic growth rate is $1.85 \mathrm{~mm} \mathrm{day}^{-1}$. Unfortunately, no references to this were found in the literature so our results could not be compared with those of other studies. For small pelagic species, there is only one other reference for this area, which reports a value of around $2 \mathrm{~mm} \mathrm{day}^{-1}$ (Cotano and Álvarez, 2003), but it is for mackerel (Scomber scombrus L.), which is a considerably larger species. This similarity in growth rate during the first growth season points out the high growth of anchovy in the Bay of Biscay.

When otolith growth was analysed, an estimated maximum growth increment of $22.19 \mu \mathrm{m}$ day $^{-1}$ was found at 56 days after hatching. Several authors have studied the otolith growth of this species in the Bay of Biscay. A study by Cermeño et al. (2008) found a maximum average increment width of $18 \mu \mathrm{m} \mathrm{day}{ }^{-1}$ for the period of 40 to 60 days after hatching, similar to those measured in the present study. However, Allain et al. $(2003,2007)$ showed an average maximum growth increment of $12 \mu \mathrm{m}$ day $^{-1}$ for 40 to 50 days after hatching. Although the difference in otolith growth between these studies is evident, a comparison is not possible as the criteria employed by Allain et al. (2003, 2007) to interpret the otolith daily increment are unknown. However, it is likely that the observed difference between these studies is related to the different interpretation criteria.

Otolith derived growth rates for juveniles during their larval stage were significantly higher than those of larvae (Fig. 9). This could provide evidence of size-selective mortality, although it is not possible to draw a definitive conclusion due to the limited the sample size. Size-selective mortality infers that individuals that develop faster and make the larval to juvenile transition at younger ages have a lower probability of mortality (Cowan et al., 1996). Furthermore, size-selective mortality in early life stages has been previously reported in several field studies (e.g. Meekan and Fortier, 1996; Hare and Cowen, 1997; Cotano and Álvarez, 2003).
A response lag of otolith growth compared with somatic growth has been observed in this study. A peak in the otolith growth rate, observed at around $53 \mathrm{~mm}$ in SL, differs from the length when the somatic growth is at a maximum, at around $82 \mathrm{~mm}$ in SL. A similar lag has been observed for other fish species (Secor and Dean, 1989; Folkvord et al., 1997; Otterlei et al., 2002), which indicates that there is not a simple proportional relationship between otolith growth and somatic growth. In terms of the function of the otolith, it may be important for young individuals to attain otoliths of a certain size quickly, while somatic growth may increase or decrease more variably under different conditions (Popper and Coombs, 1980; Neuman et al., 2001).

The relationship between SL and OR showed a characteristic change from exponential in the larval stage to linear in the juvenile stage. Recently, La Mesa et al. (2009) modelled this relationship for the same species in the Adriatic Sea and found a marked ontogenetic shift at about $40.7 \mathrm{~mm}$ in length, which would correspond to the size of anchovy at metamorphosis (Ré, 1996; Santos et al., 2007). Similar results have also been obtained by several authors for other species (Campana, 1984; Haren and Cowen, 1995; Neuman et al., 2001; Otterlei et al., 2002). This change implies that the relationship between otolith size and fish size is not constant throughout the anchovy's lifetime.

Given such a relationship, increment width is not directly proportional to growth during larval stage and the age at which increment width becomes asymptotic may mark the period of metamorphosis. Hence, unless the size at metamorphosis is known, back-calculation of growth from juveniles to larvae generally cannot be performed.

The sagittal otolith of anchovy undergoes several morphological changes such as fish growth, especially during metamorphosis. Otoliths of 35 day-old juveniles have a shape and microstructure similar to that observed in adults. In terms of the function of the otolith in hearing and maintaining equilibrium (Popper and Coombs, 1980), this adult-like otolith shape would enable fish to navigate in different environments, to pursue prey and to detect approaching predators (Xie et al., 2005). Recently, strong evidence has been provided that late larvae and early juveniles (15-30 mm in SL) are able to begin schooling behaviour (Cotano et al., 2008) and even to initiate active movement towards coastal waters (Aldanondo et al., 2010).

In the Bay of Biscay, young-of-the-year anchovy is recruited to the stock in summer and autumn. The results of this study highlight the high growth rate of this species during the larval and juvenile stages, suggesting that the Bay of Biscay provides favourable conditions for growth of anchovy during the summer months. The relationship between somatic and otolith growth is complex and influenced by ontogenetic effects. Current back-calculation techniques, which assume that otolith and somatic growth have a constant proportional relationship, should therefore be used 
with caution to account for this effect. Identifying the factors that control anchovy growth and mortality will lead to understanding the long-term changes in the abundance of the anchovy stock.

\section{ACKNOWLEDGEMENTS}

The authors wish to thank S. Xie and A. Nishimura for their useful comments about otolith development, Leire Ibaibarriaga for her assistance with statistical analysis and the anonymous referees for their constructive suggestions. Thanks are also due to M. Stutter for revising the English of this manuscript. This work was supported by a PhD grant from the Education, Universities and Research Department of the Basque Country Government and the research projects ECOANCHOA (Department of Agriculture, Fisheries and Food of the Basque Country Government) and JUVENA (Department of Agriculture, Fisheries and Food of the Basque Country Government). This paper is contribution No. 510 from AZTI-Tecnalia (Marine Research Unit).

\section{REFERENCES}

Aldanondo, N., U. Cotano, E. Etxebeste, X. Irigoien, P. Álvarez, A. Martínez de Murguía and D.L. Herrero. - 2008. Validation of daily increments deposition in the otoliths of European anchovy larvae (Engraulis encrasicolus L.) reared under different temperature conditions. Fish. Res., 93: 257-264.

Aldanondo, N., U. Cotano, M. Tiepolo, G. Boyra and X. Irigoien. -2010. Growth and movement patterns of early juvenile European anchovy (Engraulis encrasicolus L.) in the Bay of Biscay based on otolith microstructure and chemistry. Fish. Oceanogr., 19(3): 196-208.

Allain, G., P. Petitgas, P. Grellier and P. Lazure. - 2003. The selection process from larval to juvenile stages of anchovy (Engraulis encrasicolus) in the Bay of Biscay investigated by Lagrangian simulations and comparative otolith growth. Fish. Oceanogr., 12: 407-418.

Allain, G., P. Petitgas, P. Lazure and P. Grellier. - 2007. Biophysical modelling of larval drift, growth and survival for the prediction of anchovy (Engraulis encrasicolus) recruitment in the Bay of Biscay (NE Atlantic). Fish. Oceanogr., 16: 489-505.

Anderson, J.T. - 1988. A review of size dependent survival during pre-recruit stages of fishes in relation to recruitment. J. Northw. Atl. Fish. Sci., 8: 55-66.

Basilone, G., C. Guisande, B. Patti, S. Mazzola, A. Cuttitta, A. Bonanno and A. Kallianiotis. - 2004. Linking habitat conditions and growth in the European anchovy (Engraulis encrasicolus). Fish. Res., 68: 9-19.

Bellido, J.M., G.J. Pierce, J.L. Romero and M. Millán. - 2000. Use of frequency analysis methods to estimate growth of anchovy (Engraulis encrasicolus L. 1758) in the Gulf of Cádiz (SW Spain). Fish. Res., 48: 107-115.

Bellier, E., B. Planque and P. Petitgas. - 2007. Historical fluctuations in spawning location of anchovy (Engraulis encrasicolus) and sardine (Sardina pilchardus) in the Bay of Biscay during 1967-73 and 2000-2004. Fish. Oceanogr., 16: 1-15.

Borja, A., A. Uriarte, V. Valencia, L. Motos and A. Uriarte. - 1996. Relationships between anchovy (Engraulis encrasicolus L.) recruitment and the environment in the Bay of Biscay. Sci. Mar., 60(Suppl. 2): 179-192.

Borja, A., A. Uriarte, J. Egaña, L. Motos and V. Valencia. - 1998. Relationships between anchovy (Engraulis encrasicolus) recruitment and environment in the Bay of Biscay (1967-1996). Fish. Oceanogr., 7: 375-380.

Box, G.E., W.G. Hunter and J.S. Hunter. - 1978. Statistics for Experimenters. John Wiley and Sons, New York.

Butler, J.L. - 1992. Collection and preservation of material for otolith analysis. In: D.K. Stevenson and S.E. Campana (eds.),
Otolith microstructure examination and analysis. Can. Spec. Publ. Fish. Aquat. Sci., 117; 13-17.

Campana, S.E. - 1984. Microstructural growth patterns in the otoliths of larval and juvenile starry flounder, Platichthys stellatus. Can. J. Zool., 62: 1507-1512.

Campana, S.E. and J.D. Neilson. - 1985. Microstructure of fish otoliths. Can. J. Fish. Aquat. Sic., 42: 1014-1032.

Cermeño, P., A. Uriarte, A.M. De Murguía and B. Morales-Nin. 2003. Validation of daily increment formation in otoliths of juvenile and adult European anchovy. J. Fish Biol., 62: 679-691.

Cermeño, P., A. Uriarte, B. Morales-Nin, U. Cotano and P. Álvarez. - 2008. Setting up interpretation criteria for ageing juvenile european anchovy otoliths. Sci. Mar., 72(4): 733-742.

Chambers, R.C. and T.J. Miller. - 1995. Evaluating fish growth by means of otolith increment analysis: special properties of individual-level longitudinal data. In: J.D. Secor and S.E. Campana (eds.), Recent developments in fish otolith research, pp. 155175. Columbia, SC: University of South Carolina Press.

Cotano, U. and P. Álvarez. - 2003. Growth of young-of-the-year mackerel in the Bay of Biscay. J. Fish Biol., 62: 1010-1020.

Cotano, U., X. Irigoien, E. Etxebeste, P. Álvarez, L. Zarauz, J. Mader and L. Ferrer. - 2008. Distribution, growth and survival of anchovy larvae (Engraulis encrasicolus L.) in relation to hydrodynamic and trophic environment in the Bay of Biscay. $J$. Plankton Res., 30: 467-481.

Cowan, J.H., E.D. Houde and K.A. Rose. - 1996. Size-dependent vulnerability of marine fish larvae to predation: an individualbased numerical experiment. ICES J. Mar. Sci., 53: 23-37.

Dulčić, J. - 1997. Growth of anchovy, Engraulis encrasicolus (L.), larvae in the Northern Adriatic Sea. Fish. Res., 31: 189-195.

Folkvord, A., L. Ystanes, A. Johannessen and E. Moksness. - 1996. RNA:DNA ratios and growth of herring (Clupea harengus) larvae reared in mesocosms. Mar. Biol., 126: 591-602.

Folkvord, A., K. Rukan, A. Johannessen and E. Moksness. - 1997. Early life history of herring larvae in contrasting feeding environments determined by otolith microstructure analysis. J. Fish Biol., 51: 250-263.

Folkvord, A., A. Johannessen and E. Moksness. - 2004. Temperature-dependent otolith growth in Norwegian spring-spawning herring (Clupea harengus L.) larvae. Sarsia, 89: 297-310.

García, A. and I. Palomera. - 1996. Anchovy early life history and its relation to its surrounding environment in the Western Mediterranean basin. Sci. Mar., 60(Suppl. 2): 155-166.

García, A., D. Cortés, T. Ramírez, A. Giráldez and Á. Carpena. 2003. Contribution of larval growth rate variability to the recruitment of the Bay of Málaga anchovy (SW Mediterranean) during the 2000-2001 spawning seasons. Sci. Mar., 67(4): 477-490.

Geffen, A.J. - 1982. Otolith ring deposition in relation to growth rate in herring (Clupea harengus) and turbot (Scophthalmus maximus) larvae. Mar. Biol., 71: 317-326.

Hare, J.A. and R.K. Cowen. - 1995. Effect of age, growth rate, and ontogeny on the otolith size-fish size relationship in bluefish, Pomatomus saltatrix, and the implications for back-calculation of size in fish early life history stages. Can. J. Fish. Aquat. Sic., 52: 1909-1922.

Hare, J.A. and R.K. Cowen. - 1997. Size, growth, development, and survival of the planktonic larvae of Pomatomus saltatrix (Pisces: Pomatomidae). Ecology, 78: 2415-2431.

Hinrichsen, H-H., V. Buehler and C. Clemmesen. - 2007. An individual-based model for the direct conversion of otolith into somatic growth rates. Fish. Oceanogr., 16: 207-215.

Houde, E.D. - 1989. Comparative growth, mortality, and energetics of marine fish larvae: Temperature and implied latitudinal effects. Fish. Bull., 87(3): 471-495.

ICES, 2007. Report of the Working Group on the Assessment of Mackerel, Horse, Mackerel, Sardine and Anchovy (WGMHSA). 4-13 September 2007, Copenhagen: ICES Headquarters. ICES CM 2007/ACFM:31.

Irigoien, X., O. Fiksen, U. Cotano, A. Uriarte, P. Álvarez, H. Arrizabalaga, G. Boyra, M. Santos, Y. Sagarminaga, P. Otheguy, E. Etxebeste, L. Zarauz, I. Artetxe and L. Motos. - 2007. Could Biscay Bay Anchovy recruit through a spatial loophole? Prog. Oceanogr., 74: 132-148.

Irigoien, X., U. Cotano, G. Boyra, M. Santos, P. Alvarez, P. Otheguy, E. Etxebeste, A. Uriarte, L. Ferrer and L. Ibaibarriaga. -2008 . From egg to juvenile in the Bay of Biscay: spatial pat- 
terns of anchovy (Engraulis encrasicolus) recruitment in a nonupwelling region. Fish. Oceanogr., 17: 446-462.

Ivarjord, T., T. Pedersen and E. Moksness. - 2008. Effects of growth rates on the otolith increments deposition rate in capelin larvae (Mallotus villosus). J. Exp. Mar. Biol. Ecol., 358: 170-177.

Junquera, S. and G. Perez-Gándaras. - 1993. Population diversity in Bay of Biscay anchovy (Engraulis encrasicolus L. 1758) as revealed by multivariate analysis of morphometric and meristic characters. ICES J. Mar. Sci., 50: 383-391.

La Mesa, M., F. Donato, G. Giannetti and E. Arneri. - 2009. Growth and mortality rates of European anchovy (Engraulis encrasicolus) in the Adriatic Sea during the transition from larval to juvenile stages. Fish. Res., 96: 275-280.

Meekan, M.G. and L. Fortier. - 1996. Selection for fast growth during the larval life of Atlantic cod Gadus morhua on the Scotian Shelf. Mar. Ecol. Prog. Ser., 137: 25-37.

Moksness, E. - 1992. Differences in otolith microstructure and body growth rate of North Sea herring (Clupea harengus L.) larvae in the period 1987-1989. ICES J. Mar. Sci., 49: 223-230.

Morales-Nin, B. and J.P. Pertierra. - 1990. Growth rates of the anchovy Engraulis encrasicolus and the sardine Sardina pilchardus in the Northwestern Mediterranean Sea. Mar. Biol., 107: 349-356.

Mosegaard, H., H. Svedaeng and K. Taberman. - 1988. Uncoupling of somatic and otolith growth rates in Arctic char (Salvelinus alpinus) as an effect of differences in temperature response. Can. J. Fish. Aquat. Sic., 45: 1514-1524.

Motos, L., A. Uriarte and V. Valencia. - 1996. The spawning environment of the Bay of Biscay anchovy (Engraulis encrasicolus L.). Sci. Mar., 60: 117-140.

Neuman, M.J., D.A. Witting and K.W. Able. - 2001. Relationships between otolith microstructure, otolith growth, somatic growth and ontogenetic transitions in two cohorts of windowpane. $J$. Fish Biol., 58: 967-984.

Otterlei, E., A. Folkvord and G. Nyhammer. - 2002. Temperature dependent otolith growth of larval and early juvenile Atlantic cod (Gadus morhua). J. Mar. Sci., 59: 851-860.

Palomera, I., B. Morales-Nin and J. Lleonart. - 1988. Larval growth of anchovy, Engraulis encrasicolus, in the Western Mediterranean Sea. Mar. Biol., 99: 283-291.

Palomera, I., M.P. Olivar, J. Salat, A. Sabatés, M. Coll, A. García and B. Morales-Nin. - 2007. Small pelagic fish in the NW
Mediterranean Sea: An ecological review. Prog. Oceanogr., 74: 377-396.

Popper, A.N. and S. Coombs. - 1980. Auditory mechanisms in teleost fishes. Am. Sci., 68: 429-440.

Ré, P. - 1996. Anchovy spawning in Mira estuary (southwestern Portugal). Sci. Mar., 60(Suppl. 2): 141-153.

Ricker, W.E. - 1979. Growth rates and models. In: W.S. Hoar, D.J. Randall and J.R. Brett (eds.), Fish Physiology, pp. 678-743. Academic Press, New York.

Ricklefs, R.E. - 1967. A graphical method of fitting equations to growth curves. Ecology, 48: 973-983.

Santos, A.M. P. A. Chícharo, A. Dos Santos, T. Moita, P. B. Oliveira, A. Peliz and P. Ré. - 2007. Physical-biological interactions in the life history of small pelagic fish in the Western Iberia Upwelling Ecosystem. Prog. Oceanogr., 74: 192-209.

Secor, D.H. and J.M. Dean. - 1989. Somatic growth effects on the otolith-fish size relationship in young pond-reared striped bass, Morone sexatilis. Can. J. Fish. Aquat. Sic., 46: 113-121.

Simard, P., M. Castonguay, D. D'Amours and P. Magnan. 1992. Growth comparison between juvenile Atlantic mackerel (Scomber scombrus) from the two spawning groups of the Northwest Atlantic. Can. J. Fish. Aquat. Sic., 49: 2242-2248.

Somarakis, S., B. Catalano and N. Tsimenides. - 1998. Catchability and retention of larval European anchovy, Engraulis encrasicolus, with bongo nets. Fish. Bull., 96: 917-925.

Uriarte, A., P. Prouzet and B. Villamor. - 1996. Bay of Biscay and Ibero Atlantic anchovy populations and their fisheries. Sci. Mar., 60(Suppl. 2): 237-255.

Wilhelm, M.R., S.J. Painting, J.G. Field, M. Kerstan and M.D. Durholtz. - 2005. Impact of environmental factors on survival of larval and juvenile Cape anchovy Engraulis encrasicolus (G.) in the southern Benguela upwelling region, determined from hatchdate distributions: implications for recruitment. Mar. Freshwater Res., 56: 561-572.

Xie, S., Y. Watanabe, T. Saruwatari, R. Masuda, Y. Yamashita, C. Sassa and Y. Konishi. - 2005. Growth and morphological development of sagittal otoliths of larval and early juvenile Trachurus japonicus. J. Fish Biol., 66: 1704-1719.

Scient. ed.: B. Morales-Nin.

Received May 3, 2010. Accepted September 2, 2010.

Published online March 8, 2011. 